\title{
Identifikasi Bakteri yang Berperan dalam Pengasaman Kedelai dalam Fermentasi Tempe Berdasarkan Sekuen 16S rDNA
}

\section{Identification of Bacteria that Determine Soybean Acidification in Tempeh Fermentation Based on 16S rDNA Sequence}

\author{
Tati Barus $^{1 *}$ Widyah $^{2}$, Wisnu Adi Wicaksono², Vivitri Dewi Prasasty ${ }^{1}$

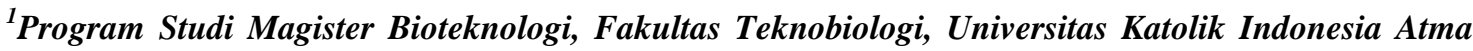 \\ Jaya. \\ Jl. Jend. Sudirman No.51, Karet Semanggi, Kec. Setiabudi, Kota Jakarta Selatan, Daerah Khusus \\ Ibukota Jakarta 12930 \\ ${ }^{2}$ Program Studi Bioteknologi, Fakultas Teknobiologi, Universitas Katolik Indonesia Atma Jaya. \\ Jl. Raya Cisauk Lapan, Sampora, Kec. Cisauk, Tangerang, Banten 15345. \\ Email: tati.barus@atmajaya.ac.id \\ *Penulis Korespondensi
}

\begin{abstract}
The fermentation process in making tempeh in Indonesia consists of two stages. The first stage is soaking the soybeans for the acidification of soybeans which is important for mold growth. In this stage the types of microbes that play a role are the bacterial group. However, information about these types of bacteria is still limited. Therefore, this study aims to identify the types of bacteria that play a role in the acidification process of soybeans during tempeh fermentation. Bacterial isolation was carried out from tempeh taken directly from tempeh craftsmen in Jakarta. Bacteria were grown on Plate Count Agar, de Man Rogosa and Sharpe Agar, Mac Conkey Agar and Eosin Methylene Blue Agar media. Furthermore, its role is tested in acidifying soybeans by measuring the $\mathrm{pH}$ of the soaking water and then the bacteria are identified. It was found that P211, P3a, Mc4b, B1p, and Man2b isolates played a role in acidification by reducing the $\mathrm{pH}$ of soybean soaking water from 7 to 4.4 to 5.6.Identification based on the $16 \mathrm{~S}$ rDNA sequence of the five bacteria were Klebsiella, Enterobacterludwigii, Enterobacter, Lactobacillus, and Pantoea sp. with a similarity of 98 $100 \%$. Furthermore, it is necessary to investigate about its role in determining the quality of tempeh.
\end{abstract}

Keywords: pH, Tempeh, Soaking, Fermentation, Soybean, Bacteria, Identification

\begin{abstract}
Abstrak
Proses fermentasi dalam pembuatan tempe di Indonesia terdiri atas dua tahap. Tahap pertama berupa perendaman kedelai untuk pengasaman kedelai yang penting bagi pertumbuhan kapang. Dalam tahapan ini jenis mikroba yang berperan adalah kelompok bakteri. Namun informasi tentang jenis bakteri tersebut masih terbatas. Oleh sebab itu penelitian ini bertujuan untuk mengidentifikasi jenis jenis bakteri yang berperan dalam proses pengasaman kedelai saat fermentasi tempe. Isolasi bakteri dilakukan dari tempe yang diambil langsung dari pengrajin tempe di Jakarta. Bakteri ditumbuhkan pada media Plate Count Agar, de Man Rogosa and Sharpe Agar, MacConkey Agar dan Eosin Methylene Blue Agar. Selanjutnya diuji perannya dalam pengasaman kedelai dengan pengukuran $\mathbf{p H}$ air rendaman kedelai dan selanjutnya bakteri tersebut diidentifikasi. Ditemukan isolat P211, P3a, Mc4b, B1p, dan Man2b berperan dalam pengasaman dengan menurunkan pH air rendaman kedelai dari 7 menjadi sekitar 4,7 hingga 5,8. Identifikasi berdasarkan sekuen 16S rDNA lima bakteri tersebut masing masing adalah Klebsiella pneumoniae, Enterobacter ludwigii, Enterobacter sp., Lactobacillus agilis, dan Pantoea sp. dengan kemiripan 98-100\%. Selanjutnya, perlu diteliti tentang perannya dalam menentukan kualitas tempe.
\end{abstract}

Kata Kunci: pH, Tempe, Perendaman, Fermentasi, Kedelai, Bakteri, Identifikasi 


\section{Pendahuluan}

Tempe kedelai (tempe) adalah makanan fermentasi tradisional dari Indonesia yang telah diproduksi dan dikonsumsi di berbagai negara di dunia. Telah dilaporkan tempe mengandung antioksidan (Barus et al., 2019b) dan merupakan sumber protein penting bagi masyarakat Indonesia karena mengandung protein yang tinggi (Barus et al., 2019a). Suplementasi tempe dapat bertindak sebagai agen para probiotik, meningkatkan produksi IgA dan peningkatan populasi Akkermansia muciniphila yang merupakan bakteri penting di saluran usus manusia (Stephanie et al., 2017). Telah dilaporkan juga bahwa tempe mengandung senyawa antibakteri (Ito et al., 2020; Roubos et al., 2010) dan bila dikonsumsi tempe selama 6 bulan bermanfaat dalam meningkatkan fungsi kognitif para orang tua usia lanjut (Handajani et al., 2020).

Fermentasi tempe terdiri atas dua tahap. Tahap pertama berupa perendaman kedelai yang telah direbus, yang berlangsung selama \pm 24 jam. Perendaman ini bertujuan untuk pengasaman kedelai yang terjadi melalui aktivitas bakteri. Pada tahap ini $\mathrm{pH}$ akan turun dari 7 menjadi sekitar 4 (Barus et al., 2008). Kondisi asam ini penting untuk pertumbuhan Rhizopus yang diinokulasikan terhadap kedelai pada tahap kedua yang berlangsung \pm 48 jam. Informasi tentang jenis-jenis bakteri yang berperan dalam pengasaman tempe masih terbatas. Informasi tentang jenis bakteri yang berperan dalam pengasaman tempe ini penting agar dapat digunakan saat produksi tempe yang diinginkan dengan kualitas yang konsisten, misalnya untuk skala industri. Untuk mendapatkan kualita tempe yang konsisten perlu ada kontrol mikroorganisme yang berperan selama fermentasi berlangsung.

Saat ini berbagai pendekatan biologi molekuler telah dikembangkan dan diterapkan untuk mengidentifikasi bakteri. Di antaranya melalui sekuensing gen 16S rRNA (Patel et al., 2001; Mignard et al., 2006) sehingga databasenya sudah tersedia dengan baik (Yoon et al., 2017). Oleh sebab itu, penelitian ini bertujuan untuk mengidentifikasi bakteri tempe yang berperan dalam pengasaman kedelai pada saat pembuatan tempe.

\section{Metode Penelitian}

\section{Isolasi Bakteri Tempe}

Empat sampel tempe diperoleh langsung dari empat pengrajin tempe yang berada di wilayah Kreo-Jakarta Selatan dan Joglo-Jakarta Barat. Sebanyak 25 g masing masing sampel dihomogenkan dengan $225 \mathrm{ml}$ $\mathrm{NaCl} 0.85 \%$ lalu dibuat seri pengencerannya. Sebanyak $100 \mu \mathrm{l}$ suspensi dari pengenceran disebar pada medium plate count agar (Difco), de Mann Rogossa Sharpesorbic agar (Oxoid), Eeosin methylene blue EMB (Merck) dan MacConkey Agar/MCA (Merck) lalu diinkubasi pada $30{ }^{\circ} \mathrm{C}$. Selanjutnya, koloni bakteri yang tumbuh dimurnikan dan disimpan pada gliserol pada suhu $-20{ }^{\circ} \mathrm{C}$ untuk dianalisis lebih lanjut.

\section{Pembuatan Tempe}

Pembuatan tempe dilakukan di laboratorium menggunakan bakteri yang telah diisolasi dari tempe untuk pengasaman kedelai. Kedelai direbus dengan akuades steril selama 30 menit, dikupas, dibuang kulitnya. Selanjutnya sebanyak 80 gram kedelai (berat basah) kemudian dicuci dengan akuades steril suhu $50^{\circ} \mathrm{C}$ sebanyak tiga kali. Kedelai direbus kembali dengan akuades steril selama 15 menit. Setelah dingin dilakukan inokulasi masing-masing isolat bakteri dengan konsentrasi $\pm 10^{7}$ sel ml ${ }^{-1}$ (Keuth \& Bisping 1994) lalu ditambah akuades steril hingga mencapai volume $240 \mathrm{ml}$. Masing-masing isolat bakteri tersebut terlebih dahulu ditumbuhkan pada $5 \mathrm{ml}$ Luria Broth (LB) selama \pm 20 jam di water bath pada $37^{\circ} \mathrm{C}, 120$ rpm. Pengukuran $\mathrm{pH}$ air rendaman kedelai dilakukan menggunakan $\mathrm{pH}$ meter di akhir perendaman. Selanjutnya kedelai dikeringkan pada suhu $30{ }^{\circ} \mathrm{C}$ lalu diinokulasi dengan $480 \mu \mathrm{l}$ $\left( \pm 10^{6} \mathrm{ml}^{-1}\right.$ spora $R$. oligosporus) (Keuth \& Bisping 1994) dari hasil pengkulturan di medium PDA yang diinkubasi pada suhu $30^{\circ} \mathrm{C}$ selama 5 hari yang disuspensikan dengan 10 $\mathrm{ml} \mathrm{NaCl} 0,85 \%$. Selanjutnya kedelai dikemas dan diinkubasi pada $30{ }^{\circ} \mathrm{C}$ selama \pm 50 jam. Penghitungan konsentrasi isolat bakteri dan spora $R$. oligosporus dilakukan menggunakan hemositometer. 


\section{Identifikasi Bakteri}

Isolasi genom bakteri dilakukan dengan metode cethyl trimethyl ammonium bromide (CTAB) (Minas et al., 2011. Isolat bakteri ditumbuhkan pada $5 \mathrm{ml}$ medium LB selama \pm 20 jam di water bath pada $37^{\circ} \mathrm{C}, 120$ rpm. Suspensi bakteri tersebut disentrifugasi pada $10.000 \mathrm{rpm}$ selama 3 menit kemudian supernatannya dibuang. Pelet diresuspensi dengan $400 \mu \mathrm{l}$ TE $1 X$ lalu ditambahkan $100 \mu \mathrm{l}$ lisozim dengan konsentrasi $50 \mathrm{mg} \mathrm{ml}^{-1}$ untuk bakteri Gram positif (tahap ini tidak dilakukan untuk bakteri Gram negatif) dan kemudian diinkubasi pada suhu $37^{\circ} \mathrm{C}$ selama 1 jam sambil dibolak-balik setiap 15 menit sekali. Selanjutnya ditambahkan $100 \mu$ l SDS $10 \%$ dan dibolak-balik sampai suspensi bening dan kental. Suspensi ditambahkan dengan $10 \mu \mathrm{l}$ proteinase-K dengan konsentrasi $10 \mathrm{mg} \mathrm{ml}^{-1}$ dan diinkubasi pada suhu $37^{\circ} \mathrm{C}$ selama 1 jam sambil dibolak-balik setiap 15 menit sekali. Selanjutnya ditambahkan $100 \mu \mathrm{l} \mathrm{NaCl} 5 \mathrm{M}$ dan $100 \mu \mathrm{l}$ CTAB $10 \%$ lalu dibolak-balik sampai putih dan kemudian diinkubasi pada suhu 65 ${ }^{\circ} \mathrm{C}$ selama 20 menit. $500 \mu \mathrm{l}$ fenol-kloroformisoamil alkohol (25:24:1) ditambahkan ke dalam tabung dan divorteks sampai suspensi berwarna putih. Suspensi disentrifugasi pada $10.000 \mathrm{rpm}$ selama 10 menit, supernatannya dipindahkan ke tabung mikro baru, ditambahkan dengan $500 \mu 1$ kloroform-isoamil alkohol (24:1), dan disentrifugasi pada 10.000 rpm selama 10 menit. Supernatan diambil dan dihitung volume yang diambil, ditambahkan dengan isopropanol absolut dingin sesuai dengan volume supernatan yang diambil, suspensi diresuspensi, diinkubasi pada suhu $20^{\circ} \mathrm{C}$ selama 1 jam, dibolak-balik sampai terlihat benang putih, dan disentrifugasi pada $10.000 \mathrm{rpm}$ selama 10 menit. Supernatan dibuang, ditambahkan dengan $700 \mu 1$ etanol $70 \%$, dan disentrifugasicepat sebanyak dua kali. Setelah itu, supernatan dibuang, pelet DNA dikeringkan dengan pompa vakum, diresuspensi dengan $25 \mu \mathrm{l} \mathrm{ddH}_{2} \mathrm{O}$, dan disimpan pada suhu $-20^{\circ} \mathrm{C}$.

Komposisi reaksi PCR terdiri atas 25 $\mu 1$ Gotaq (Promega, Amerika Serikat), $2 \mu 1$ primer $63 f\left(25 \mathrm{pmol}^{\mu \mathrm{l}^{-1}}\right)\left(5^{\prime}\right.$ - CAG GCC TAA CAC ATG CAA GTC -3'), $2 \mu 1$ primer $1387 \mathrm{r}$ $\left(25\right.$ pmol $\left.\mu \mathrm{l}^{-1}\right)$ (5' - GGG CGG WGT GTA CAA GGC -3') dan $19 \mu 1$ nuclease free water. Sebanyak $2 \mu 1$ hasil isolasi genom dimasukkan ke dalam master mix, kemudian dijalankan pada mesin PCR (Perkin Elmer, Gene Amplification System 2400) dengan tahapan sebagai berikut: predenaturasi pada $94{ }^{\circ} \mathrm{C}$ selama 5 menit, denaturasi pada $92^{\circ} \mathrm{C}$ selama 30 detik, annealing pada $62^{\circ} \mathrm{C}$ selama 30 detik, extension pada $72^{\circ} \mathrm{C}$ selama 30 detik, post extension pada $72^{\circ} \mathrm{C}$ selama 7 menit, hold pada $4^{\circ} \mathrm{C}$ dengan 30 siklus PCR (Barus et al., 2008).

Produk PCR divisualisasi dalam agarosa $1 \%$ pada tegangan 60 volt selama 1 jam, diikuti pewarnaan dengan etidium bromida. Marker yang digunakan adalah $1 \mathrm{~kb}$ ladder (Fermentas, Amerika Serikat). Pita DNA berukuran $\pm 1.3 \mathrm{~kb}$ dipurifikasi dari gel dengan QIAquick Gel Extraction Kit (Qiagen, Jerman). DNA disekuensing dengan ABI PRISM 310 Automated Sequencer(Applied Biosystem, Amerika Serikat). Data sekuen dibandingkan dengan basis data GenBank dengan perangkat lunak BLASTN (www.ncbi.nlm.nih.gov).

\section{Hasil dan Pembahasan}

Dari empat sampel tempe yang digunakan berhasil diisolasi dan dimurnikan sebanyak 21 isolat bakteri setelah melalui uji Gram dan morfologi (Gambar 1 sebagai perwakilan). Namun dari 21 isolat tersebut ditemukan 5 isolat yang berperan dalam pengasaman kedelai saat pembuatan tempe, yaitu P211, P3a, Mc4b, B1p, dan Man2b, di mana isolat tersebut dapat menurunkan $\mathrm{pH}$ air rendaman kedelai dari $\mathrm{pH} 7$ menjadi sekitar 4,7-5,8 (Tabel 1). Pada pengrajin tempe, pada tahap perendaman yang berlangsung sekitar 24 jam telah dilaporkan $\mathrm{pH}$ air rendaman kedelai akan turun dari 7 menjadi sekitar 4 (Barus et al., 2008). Di Indonesia, pengasaman tersebut terjadi secara alami yang dilakukan oleh berbagai jenis bakteri. Selain secara alami, proses pengasaman kedelai saat pembuatan tempe dapat juga secara kimia dengan menambahkan senyawa sintetik, seperti asam asetat (Barus et al., 2019a). 


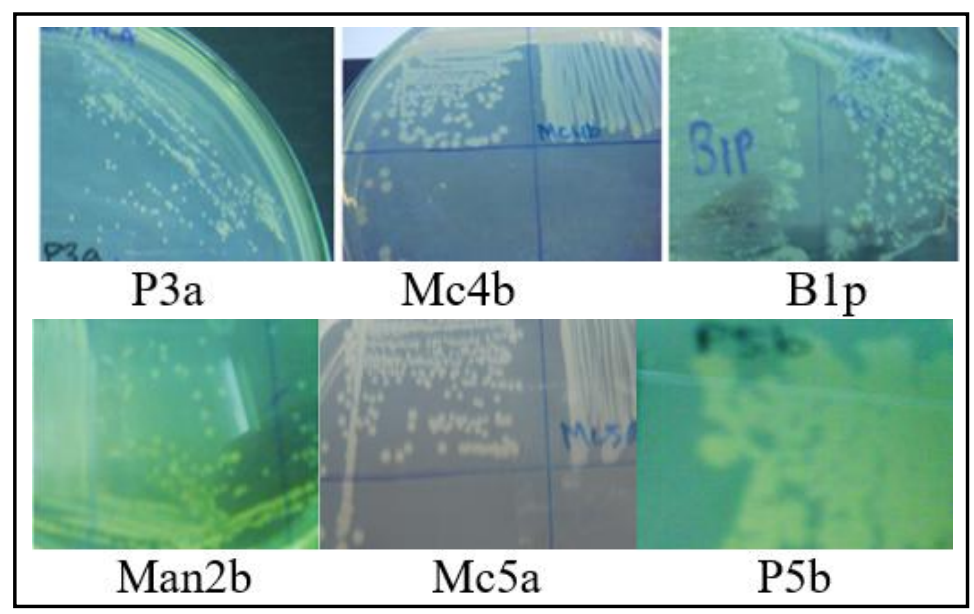

Gambar 1. Koloni bakteri yang diisolasi dari tempe

Genom lima bakteri tersebut telah berhasil diisolasi menggunakan metode CTAB. Amplifikasi PCR dari sekuens 16S rDNA telah berhasil dilakukan dan masing masing menghasilkan fragmen DNA dengan pita tunggal yang berukuran 1.300 bp (Gambar tidak ditampilkan). Hasil BLASTN dari urutan sekuen 16S rDNA (sekitar 800 hingga 950 nukleotida) dari isolat P211, P3a, Mc4b, B1p, dan Man2b secara berurutan merupakan Klebsiella pneumoniae, Enterobacter ludwigii, Enterobacter sp., Lactobacillus agilis, dan Pantoea sp. dengan kemiripan 98-100\% (Tabel $1)$.

Semua bakteri tersebut merupakan jenis bakteri yang telah dilaporkan keberadaannya pada tempe. Keberadaan $L$. agilis telah dilaporkan oleh Pangastuti et al., (2019) dan merupakan jenis bakteri yang dominan pada tempe (Radita et al., 2017).

Bakteri ini merupakan anggota dari kelompok bakteri asam laktat yang telah dilaporkan berperan dalam pengasaman kedelai tempe. Kelompok Enterobacter merupakan bakteri yang melimpah pada tempe. Barus et al., (2008) melaporkan bahwa kelimpahannya pada air rendaman kedelai di salah satu pengrajin tempe mencapai $10^{6} \mathrm{CFU}$ $\mathrm{ml}^{-1}$ di awal perendaman dan mencapai $10^{8}$ CFU $\mathrm{ml}^{-1}$ di akhir perendaman. Namun, perannya dalam menurunkan $\mathrm{pH}$ untuk pengasaman kedelai tempe belum pernah dilaporkan.

Kondisi $\mathrm{pH}$ rendah penentu keberhasilan pembuatan tempe mengakibatkan terjadinya pengasaman pada kedelai. Kondisi asam kedelai tersebut dibutuhkan bagi pertumbuhan $R$ microspores (jamur tempe). Menurut Barus et al., (2008) penurunan $\mathrm{pH}$ air rendaman kedelai dapat bervariasi antar pengrajin tempe. Pada pengrajin tempe WJB $\mathrm{pH}$ air rendaman kedelai turun dari $\mathrm{pH} 7$ (awal perendaman) menjadi $\mathrm{pH}$ 5,0 (setelah 24 jam perendaman). Pada pengrajin tempe EMP $\mathrm{pH}$ air rendaman kedelai turun dari $\mathrm{pH} 7$ (awal perendaman) menjadi $\mathrm{pH} \mathrm{4,7} \mathrm{(setelah} 24$ jam perendaman). Tabel 1 menunjukkan bahwa peran bakteri bervariasi dalam menurunkan $\mathrm{pH}$ air rendaman. Lactobacillus dapat menurunkan $\mathrm{pH}$ paling rendah $(4,6)$ dan paling tinggi Enterobacter ludwigii (5,8). Pada $\mathrm{pH}$ 5,8 tempe masih berhasil diproduksi karena $R$. microspores masih dapat tumbuh dengan baik.

Dari Tabel 1 dapat dilihat bahwa $K$. pneumoniae dapat menurunkan $\mathrm{pH}$ air rendaman saat perendaman kedelai.Artinya $K$. pneumoniae dapat mengasamkan kedelai yang merupakan hal penting pada pembuatan tempe. Telah dilaporkan banyak hal tentang bakteri $K$. pneumoniae pada tempe tersebut. Diantaranya $K$. pneumoniae telah dilaporkan berperan dalam pembentukan vitamin $\mathrm{B}_{12}$ pada tempe (Keuth \& Bisping, 1994) dan merupakan salah satu jenis bakteri yang melimpah pada tempe (Barus et al., 2013). Podschun \& Ullmann, (1998) K. pneumoniae bersifat patogen oportunistik, namun secara genetik $K$. Pneumoniaepada tempe berbeda dengan $K$. pneumoniae patogen (Ayu et al., 2014). Akan tetapi, $K$. pneumoniae yang berperan dalam pengasaman kedelai pada pembuatan tempe baru pertama ini dilaporkan. 
Tati Barus et al.

Tabel 1. Isolat dan identitas bakteri tempe yang berperan dalam pengasaman kedelai saat fermentasi tempe

\begin{tabular}{|c|c|c|c|c|}
\hline $\begin{array}{l}\text { Kode } \\
\text { isolat }\end{array}$ & Gram & Identitas Bakteri (\% similaritas) & $\begin{array}{c}\text { pH air } \\
\text { rendaman }\end{array}$ & Tempe yang dihasilkan \\
\hline P211 & - & Klebsiella $(98 \%)$ & 5,2 & \\
\hline P3a & - & Enterobacter ludwigii (100\%) & 5,8 & \\
\hline $\mathrm{Mc} 4 \mathrm{~b}$ & - & Enterobacter $(98 \%)$ & 5,5 & \\
\hline B1p & - & Lactobacillus $(98 \%)$ & 4,7 & \\
\hline $\operatorname{Man} 2 b$ & - & Pantoea sp. galur B1 (100\%) & 5,6 & \\
\hline
\end{tabular}

Tempe merupakan produk pangan fermentasi yang beredar secara luas di Indonesia. Oleh karena itu, dibutuhkannya standar yang berlaku untuk menjaga keamanan pangan dan melindungi kualitas kesehatan dari konsumen. Standar yang berlaku tersebut adalah Standar Nasional Indonesia (SNI) 3144:2015 yang ditetapkan oleh Badan Standardisasi Nasional (BSN) tahun 2015. Tempe yang dihasilkan pada penelitian menggunakan isolat P211, P3a, Mc4b, B1p, dan Man2b telah berhasil diproduksi. Semua tempe (Tabel 1) memenuhi syarat mutu tempe yang tertera pada SNI 3144:2015, dalamhal bertekstur kompak dan tetap utuh saat diiris. Berwarna putih merata pada seluruh permukaan karena Rhizopus dapat tumbuh dengan baik. Aroma tempe yang dihasilkan juga berbau khas tempe tanpa bau amoniak.

Telah dilaporkan bahwa sejak awal hingga akhir fermentasi tempe, jenis dan jumlah bakteri yang berperan di dalamnya sangat beragam (Radita et al., 2018; Efriwati et al., 2013). Makromolekul kedelai yang komplek menjadi lebih sederhana setelah diolah menjadi tempe akibat aktivitas enzimatik dari mikroba. Aktivitas antioksidan tempe juga ditentukan oleh mikroba (Barus et al., 2019b). Masing-masing mikroba memiliki aktivitas enzimatik yang bervariasi, seperti aktivitas protease Bacillus spp. yang melimpah pada tempe juga bervariasi antar isolatnya (Barus et al., 2017). Namun, untuk mendapatkan kualitas tempe yang baik dan konsisten sulit diperoleh bila mikroba yang berperan selama fermentasi tidak terkontrol. Oleh sebab itu, implikasi dari temuan hasil penelitian ini bermanfaat saat dibutuhkan tempe dengan pengasaman alami oleh bakteri dan dibutuhkan kualitas tempe yang konsisten maka dapat digunakan bakteri tersebut untuk pengasaman kedelai.

Namun telah dilaporkan bahwa mikroba berperan penting dalam menentukan kualitas pangan fermentasi. Seperti Lactobacillus plantarum berperan dalam menentukan organoleptik tape singkong (Barus \& Wijaya, 2011). Cita rasa tape singkong paling diminati oleh panelis bila difermentasi menggunakan campuran yeast dan $L$. 
plantarum (Barus \& Wijaya, 2011). Oleh sebab itu, penting dianalisis lebih lanjut tentang peran isolat P211, P3a, Mc4b, B1p, dan Man2b dalam menentukan kualitas tempe. Misalnya dalam hal perannya dalam menentukan cita rasa dan kandungan senyawa tertentu pada tempe.

\section{Simpulan}

Klebsiella pneumoniae, Enterobacter ludwigii, Enterobacter sp.,Lactobacillus agilis, dan Pantoea sp. berperan berperan dalam pengasaman kedelai karena dapat menurunkan $\mathrm{pH}$ air rendaman kedelai hingga 4,7-5,8. Pada kondisi tersebut Rhizopus dapat tumbuh dengan baik sehingga pembuatan tempe berhasil dilakukan. Namun perlu dianalisis lebih lanjut peran bakteri tersebut dalam menentukan kualitas tempe.

\section{Ucapan Terima Kasih}

Terima kasih kepada UNIKA Atma Jaya yang telah mendanai penelitian ini melalui hibah kompetitif.

\section{Daftar Pustaka}

Ayu, E., Suwanto, A., \& Barus, T. (2014). Klebsiella pneumoniae from Indonesian tempeh were genetically different from that of pathogenic isolates. Microbiology Indonesia 8(1): 58-64.

Barus, T., \& Wijaya, L.N. (2011). Mikrobiota dominan dan perannya dalam cita rasa tape singkong. Biota: Jurnal Ilmiah Ilmu-Ilmu Hayati 16(2): 354-561.

Barus, T., Hanjaya, I., Sadeli, J., LAY, B.W., Suwanto A, \& Yulandi, A. (2013). Genetic diversity of Klebsiella spp. isolated from tempe based on enterobacterial repetitive intergenic consensus-polymerase chain reaction (ERIC-PCR). HAYATI Journal of Biosciences 20(4): 171-176.

Barus, T., Maya, F., \& Hartanti, A.T. (2019a). Peran Beberapa Galur Rhizopus microsporus yang Berasal dari "laru tradisional" dalam Menentukan Kualitas Tempe. Jurnal Aplikasi Teknologi Pangan 8(1):17-22.
Barus, T., Suwanto, A., Wahyudi, A. T., \& Wijaya, H. (2008). Role of bacteria in tempe bitter taste formation: microbiological and molecular biological analysis based on 16S rRNA gene. Microbiology Indonesia 2(1):17-21.

Barus, T., Titarsole, N.N., Mulyono, N., \& Prasasty, V.D. (2019b). Tempeh Antioxidant Activity using DPPH Method: Effects of Fermentation, Processing, and Microorganisms. Journal of Food Engineering and Technology 8(2): 75-80.

Barus, T., Wati, L., \& Suwanto, A. (2017). Diversity of protease-producing Bacillus spp. from fresh Indonesian tempeh based on 16S rRNA gene sequence. HAYATI Journal of Biosciences 24(1): 35-40.

Efriwati, Suwanto, A., Rahayu, G., \& Nuraida, L. (2013). Population dynamics of yeasts and lactic acid bacteria (LAB) during tempeh production. HAYATI Journal of Biosciences 20(2): 57-64.

Handajani, Y.S., Turana, Y., Yogiara, Y., Widjaja, N.T., Sani, T.P., Christianto, G.A.M., \& Suwanto, A. (2020). Tempeh Consumption and Cognitive Improvement in Mild Cognitive Impairment. Dementia and geriatric cognitive disorders 49:497502

Ito, M., Ito, T., Aoki, H., Nishioka, K., Shiokawa, T., Tada, H., \&Takashiba, S. (2020). Isolation and identification of the antimicrobial substance included in tempeh using Rhizopus stolonifer NBRC 30816 for fermentation. International Journal of Food Microbiology 325: 1-6.

Keuth, S., \& Bisping, B. (1994). Vitamin B12 production by Citrobacter freundii or Klebsiella pneumoniae during tempeh fermentation and proof of enterotoxin absence by PCR. Applied and environmental microbiology 60(5): 14951499.

Minas, K., McEwan, N.R., Newbold, C.J., \& Scott, K.P. (2011). Optimization of a highthroughput CTAB-based protocol for the extraction of qPCR-grade DNA from rumen fluid, plant and bacterial pure cultures. FEMS microbiology letters, 325(2): 162-169.

Pangastuti, A., Alfisah, R.K., Istiana,N.I., Arum, Siti Lusi Arum Sari, Ratna Setyaningsih, Ari Susilowati, \& Tjahjadi Purwoko. (2019). Metagenomic analysis of microbial community in over-fermented 


\section{Tati Barus et al.}

tempeh. Biodiversitas Journal of Biological Diversity 20(4): 1106-1114.

Patel, J.B. (2001). 16S rRNA gene sequencing for bacterial pathogen identification in the clinical diagnosis6(4): 313-321.

Podschun R., \& Ullmann U. (1998). Klebsiella spp. as nosocomial pathogens: epidemiology, taxonomy, typing methods, and pathogenicity factors. Clinical Microbiology Reviews 11:589-603.

Radita, R., Suwanto, A., Kurosawa, N., Wahyudi, A.T., \& Rusmana, I. (2018). Firmicutes is the predominant bacteria in tempeh. International Food Research Journal 25(6): 2313-2320.

Radita, R., Suwanto, A., Kurosawa, N., Wahyudi, A.T. \& Rusmana, I., (2017). Metagenome analysis of tempeh production: Where did the bacterial community in tempeh come from?.Malaysian Journal of Microbiology 13(4): 280-288.
Roubos-van den Hil, P.J., Nout, M.R., van der Meulen, J., \& Gruppen, H. (2010). Bioactivity of tempe by inhibiting adhesion of ETEC to intestinal cells, as influenced by fermentation substrates and starter pure cultures. Food microbiology 27(5): 638-644.

SNI (Standar Nasional Indonesia) 3144-2015. (2015). Tempe Kedelai. Badan Standarisasi Nasional. Jakarta

Stephanie, S., Ratih, N.K., Soka, S., \& Suwanto, A. (2017). Effect of tempeh supplementation on the profiles of human intestinal immune system and gut microbiota. Microbiology Indonesia 11(1); 11-17.

Yoon, S.H., Ha, S.M., Kwon, S., Lim, J., Kim, Y., Seo, H., \& Chun, J. (2017). Introducing EzBioCloud: a taxonomically united database of 16S rRNA gene sequences and whole-genome assemblies. International journal of systematic and evolutionary microbiology 67(5):1613-1617. 